\title{
Diagnosis, classification, and management of erythema multiforme and Stevens-Johnson syndrome
}

\author{
C Léauté-Labrèze, T Lamireau, D Chawki, J Maleville, A Taïeb
}

\begin{abstract}
Background-In adults, erythema multiforme (EM) is thought to be mainly related to herpes infection and StevensJohnson syndrome (SJS) to drug reactions.

Aims-To investigate this hypothesis in children, and to review our experience in the management of these patients.

Methods-A retrospective analysis of 77 paediatric cases of EM or SJS admitted to the Children's Hospital in Bordeaux between 1974 and 1998.

Results-Thirty five cases, inadequately documented or misdiagnosed mostly as urticarias or non-EM drug reactions were excluded. Among the remaining 42 patients (14 girls and 28 boys), 22 had EM (11 EM minor and 11 EM major), 17 had SJS, and three had isolated mucous membrane involvement and were classified separately. Childhood EM was mostly related to herpes infection and SJS to infectious agents, especially Mycoplasma pneumoniae. Only two cases were firmly attributed to drugs (antibiotics). No patient died. EM and SIS sequelae were minor and steroids were of no overall benefit. Conclusion-In paediatric practice EM is frequently misdiagnosed. The proposal that SJS is drug related in adults does not apply to children, and in our recruitment EM and SJS are mostly triggered by infectious agents. The course of both diseases, even though dramatic at onset, leads to low morbidity and mortality when appropriate symptomatic treatment is given. (Arch Dis Child 2000;83:347-352)
\end{abstract}

Unité de Dermatologie Pédiatrique, Hôpital Pellegrin-Enfants, Place Amélie

Raba-Leon, 33076

Bordeaux Cedex,

France

C Léauté-Labrèze

J Maleville

A Taïb

Service de Pédiatrie, Hôpital

Pellegrin-Enfants

T Lamireau

D Chawki

Correspondence to:

Prof. Tä̈b

email:

alain.taieb@u-bordeaux2.f

Accepted 24 May 2000

Erythema multiforme (EM) is an acute, self-limiting disease of the skin and mucous membranes described by Hebra in $1866^{1}$; it is characterised by symmetrically distributed skin lesions, located primarily on the extremities, and by a tendency for recurrences. EM is said to be rare in childhood, and very few paediatric series concern EM. ${ }^{2-13}$ Most series include adults and children, and when they concern only children, Stevens-Johnson syndrome (SJS) and EM are not distinguished. In 1922 Stevens and Johnson described two children who had fever, conjunctivitis, stomatitis, and a generalised exanthema with skin lesions distinct from $\mathrm{EM}^{14}$; but in the past 30 years it has become widely accepted that EM and SJS, as well as toxic epidermal necrolysis, are all part of a single "EM spectrum". In both EM and SJS, pathological changes in the earliest skin lesion consist of the accumulation of mononuclear cells around the superficial dermal blood vessels; epidermal damage is more characteristic of EM with keratinocyte necrosis leading to multilocular intraepidermal blisters. ${ }^{5}$ In fact, there is little clinical resemblance between typical EM and SJS, and recently some authors have proposed a reconsideration of the "spectrum" concept and a return to the original description..$^{15-17}$ According to these authors, the term EM should be restricted to acrally distributed typical targets or raised oedematous papules. Depending on the presence or absence of mucous membrane erosions the cases may be classified as EM major or EM minor. ${ }^{16}$ The term SJS should be used for a syndrome characterised by mucous membrane erosions and widespread blisters, often predominant on the chest, and presenting with erythematous or purpuric macules. ${ }^{17}$

We have carried out a retrospective analysis of all patients under 15 years of age, hospitalised for EM or SJS over a 20 year period at the Children's Hospital in Bordeaux. Our aims were: (1) to classify childhood EM and SJS according to the clinical criteria of BastujiGarin and colleagues ${ }^{15}$; (2) to study in children the hypothesis that typical EM is mainly related to herpes simplex virus and SJS to drug reactions, as previously shown in adults ${ }^{17}$; and (3) to review our experience in the diagnosis and management of children with EM.

\section{Patients and methods}

Three of us (CLL, DC, and JM) reviewed all the records and photographs of 77 children admitted for EM or SJS in all paediatric wards of our hospital between 1974 and 1996.
CLINICAL CLASSIFICATION

All cases were classified according to the following criteria ${ }^{16}$ :

- EM minor: typical targets or raised oedematous papules acrally distributed (fig 1)

- EM major: as above, with involvement of one or more mucous membranes

- SFS: widespread blisters predominant on the chest, presenting with erythematous or purpuric macules and one or more mucous membrane erosions (fig 2).

CRITERIA FOR AETIOLOGICAL ATTRIBUTION

Herpes-Because herpes aetiology is questionable in most cases of EM, we decided to use the 

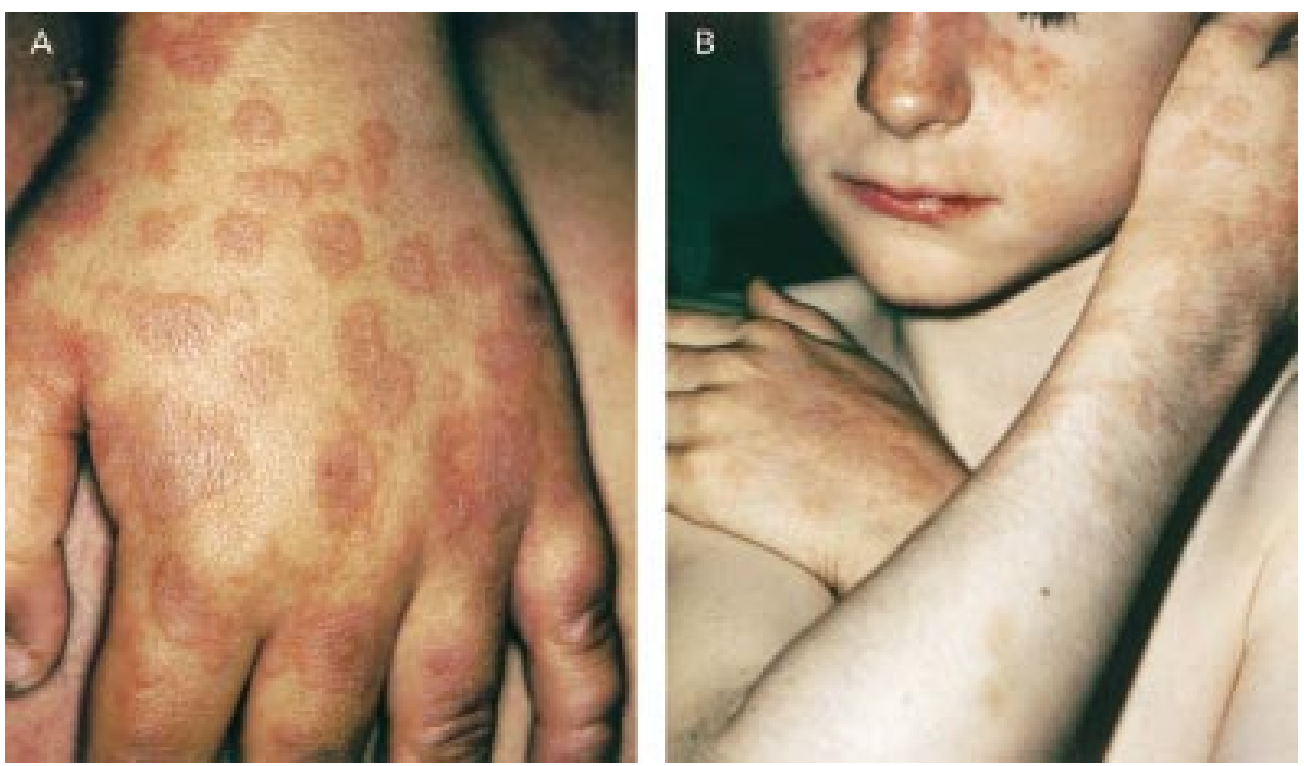

Figure 1 (A) Typical targets of EM associated with raised oedematous papules on hand. (B) Typical targets of EM acrally distributed in a child with labial herpes.

herpes score of Assier and colleagues. ${ }^{17}$ This score (0-4) was established by adding the following criteria (one point each): recurrent EM, history of recurrent herpes, recent clinical herpes (preceding EM within three weeks), and a demonstration of a recent herpes simplex virus infection (virus isolation, positive immunofluorescence, or seroconversion). EM was firmly attributed to herpes simplex virus infection for a score of 2 or more, without any other suspected aetiology. Herpes virus infection was only suspected for a score of 1 .

SJS was only attributed to Mycoplasma pneumoniae (MP) when there was positive MP complement fixation titre and/or isolation of MP on throat cultures. MP was only suspected in cases of associated febrile pneumonia without bacteriological confirmation.

An infectious aetiology was suspected when a preceding illness was noticed without drug ingestion.

All drug ingestions during the preceding two weeks were recorded, and EM or SJS were attributed to drugs according to the official
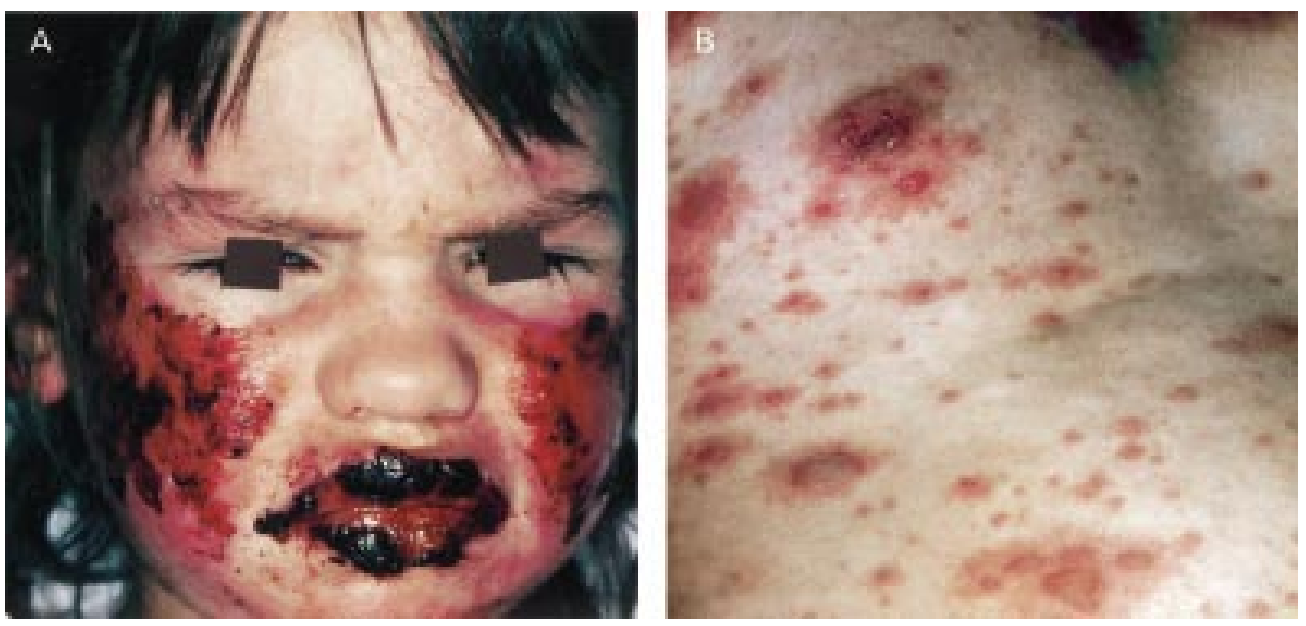

Figure 2 (A) SFS with skin and major mucous membrane involvement. (B) Widespead blisters of the chest in a child with SFS.

French algorithm used for reporting adverse drug reactions. ${ }^{18} \mathrm{~A}$ score is calculated on the basis of chronological and semiological criteria of skin manifestations; a minimum score of 3 is required to suspect drug involvement. In case of drug intake during infection, the possible involvement of both causes was taken into account.

\section{Results}

Eleven cases were inadequately documented and excluded from the study.

DIFFERENTIAL DIAGNOSIS OF EM AND SJS

Twenty four of 66 cases were clearly not affected by EM or SJS. Among these patients nine had urticaria, seven had non-EM drug reactions (maculopapular rash in five cases and toxic pustuloderma in two cases), two children had papular urticaria, two others acute haemorrhagic oedema, and two cases had varicella. Kawasaki disease and staphylococcal scalded skin syndrome were also noted (one case each). 
Table 1 Patients with erythema multiforme

\begin{tabular}{|c|c|c|c|c|c|c|c|c|}
\hline No., sex & Age (y) & Preceding illness & $\begin{array}{l}\text { Drug ingestion one } \\
\text { week before }\end{array}$ & Suspected aetiology & $\begin{array}{l}\text { Duration of } \\
\text { disease }\end{array}$ & $\begin{array}{l}\text { Steroids } \\
\text { Yes/no }\end{array}$ & $\begin{array}{l}\text { Recurrences } \\
\text { Yes/no }\end{array}$ & $\begin{array}{l}\text { Sequelae } \\
\text { Yes/no }\end{array}$ \\
\hline \multicolumn{9}{|c|}{ Erythema multiforme minor } \\
\hline $1, M$ & 8 months & Immunisation ${ }^{\star}$ & None & Immunisation ${ }^{\star}$ & 10 days & No & No & No \\
\hline $2, \mathrm{M}$ & 1 & Immunisation $\ddagger$ & None & Immunisation ${ }^{\star}$ & 10 days & No & No & No \\
\hline $3, \mathrm{~F}$ & 4 & Pharyngitis & Ampicillin (2) & Infection or antibiotics & 10 days & No & No & No \\
\hline $4, \mathrm{M}$ & 6 & None & None & Tuberculin & 10 days & No & No & No \\
\hline $5, M$ & 9 & Labial herpes & None & Herpes (3) & 10 days & No & Yes & No \\
\hline $6, \mathrm{~F}$ & 9 & Dyshidrosis & Oxacillin (2) & Herpes (1) or oxacillin & 20 days & No & No & No \\
\hline $7, \mathrm{M}$ & 10 & None & None & Herpes (1)? & 15 days & No & Yes & No \\
\hline $8, \mathrm{M}$ & 11 & Labial herpes & None & Herpes (2) & 8 days & Yes & $?$ & No \\
\hline $9, \mathrm{~F}$ & 12 & None & None & Herpes (2)? & 15 days & No & Yes & No \\
\hline $10, M$ & 15 & Labial herpes & None & Herpes (2) & ? & No & ? & No \\
\hline $11, \mathrm{M}$ & 15 & Labial herpes & None & Herpes (3) & 8 days & No & Yes & No \\
\hline \multicolumn{9}{|c|}{ Erythema multiforme major } \\
\hline $12, \mathrm{M}$ & 4 & orf & Acyclovir (1) & orf & 10 days & No & No & No \\
\hline$\star 13, M$ & 6 & Bronchoendoscopy & Ampicillin (3) & Ampicillin & 10 days & No & No & No \\
\hline${ }^{\star} 14, \mathrm{M}$ & 10 & Tonsillitis & None & Streptococcus A? & 15 days & No & No & No \\
\hline $15, \mathrm{~F}$ & 10 & None & None & Herpes (1)? & ? & No & Yes & No \\
\hline${ }^{\star} 16, \mathrm{~F}$ & 12 & $?$ & None & Herpes (1)? & $?$ & No & Yes & No \\
\hline $17, M$ & 13 & Immunisation* & None & Immunisation? $\dagger$ & ? & Yes & Yes & No \\
\hline $18, M$ & 13 & Labial herpes & None & Herpes (3) & $?$ & No & Yes & No \\
\hline $19, M$ & 13 & Labial herpes & None & Herpes (2) & ? & No & $?$ & No \\
\hline$\star 20, M$ & 13 & Labial herpes & None & Herpes (3) & $?$ & No & Yes & No \\
\hline $21, \mathrm{~F}$ & 14 & Tonsillitis & $\begin{array}{l}\text { Ampicillin (2) } \\
\text { Niflumic acid (2) }\end{array}$ & Infection or drugs? & $?$ & No & No & No \\
\hline$\star_{2} 2, \mathrm{M}$ & 14 & Upper respiratory tract infections & None & Sinusitis? & 20 days & $\begin{array}{l}\text { Yes }+ \\
\text { thalidomide }\end{array}$ & Yes & No \\
\hline
\end{tabular}

Herpes and drug scores are in brackets.

*Vaccine.

†Immunisation against diphtheria-tetanus-poliomyelitis.

$\ddagger$ Immunisation against measles-mumps-rubella.

CLINICAL CLASSIFICATION

Forty two patients could be evaluated: 22 children had EM (11 EM minor and 11 EM major), and 17 had SJS (tables 1, 2, and 3). Three children had mucous membrane symptoms, without any cutaneous lesions. The eye, oral cavity, and genitalia were all involved. We were unable to classify these patients as EM major or SJS according to the criteria.

There was a male predominance ( 28 boys and 14 girls), especially in the group of EM patients ( 16 boys and six girls, sex ratio 2.6).
Mean age was 8.7 years (range 8 months to 15 years). The mean age of EM patients was higher than that of SJS patients (9.7 years versus 7.8 years).

AETiOlogy of THE DisEASE

Infections

In 27 patients, aetiology of the disease was attributed to infectious agents: 14 of 22 cases of EM, 11 of 17 cases of SJS; and two of three patients with mucous membrane involvement.

Herpes was associated with EM but not SJS. In eight of 22 patients, EM was attributed to

Table 2 Patients with Stevens-fohnsons syndrome and mucous membrane involvement only

\begin{tabular}{|c|c|c|c|c|c|c|c|c|}
\hline No., sex & Age (y) & Preceding illness & $\begin{array}{l}\text { Drug ingestion one week } \\
\text { before }\end{array}$ & Suspected aetiology & $\begin{array}{l}\text { Duration of } \\
\text { disease }\end{array}$ & $\begin{array}{l}\text { Steroids } \\
\text { Yes/no }\end{array}$ & $\begin{array}{l}\text { Recurrences } \\
\text { Yes/no }\end{array}$ & Sequelae \\
\hline \multicolumn{9}{|c|}{ Stevens-fohnson syndrome } \\
\hline $23, \mathrm{~F}$ & 2 & $\begin{array}{l}\text { Measles } \\
\text { Immunisation }\end{array}$ & No & $\begin{array}{l}\text { Measles } \\
\text { or immunisation }\end{array}$ & 12 days & No & No & No \\
\hline $24, \mathrm{~F}$ & 4 & Hyperthermia & No & Infection & 20 days & No & No & $\begin{array}{l}\text { Cutaneous } \\
\text { dyschromia }\end{array}$ \\
\hline $25, \mathrm{~F}$ & 5 & Upper respiratory tract infection & No & M pneumoniae? & 15 days & No & No & No \\
\hline $26, M$ & 6 & Pneumopathy & No & M pneumoniae & 15 days & Yes & No & No \\
\hline $27, M$ & 6 & Pneumopathy & $\begin{array}{l}\text { Ampicillin (2) } \\
\text { Ibuprofen (2) }\end{array}$ & M pneumoniae & 12 days & $\begin{array}{l}\text { No } \\
\text { Thalidomide }\end{array}$ & No & No \\
\hline $28, M$ & 7 & Hyperthermia & No & Infection & 20 days & Yes & No & Labial synechiae \\
\hline $29, \mathrm{~F}$ & 7 & Pneumopathy & No & M pneumoniae & 20 days & Yes & No & $\begin{array}{l}\text { Ocular synechiae } \\
\text { Dyschromia }\end{array}$ \\
\hline $30, M$ & 8 & Pneumopathy & No & M pneumoniae? & 20 days & Yes & No & Dyschromia \\
\hline $31, \mathrm{M}$ & 8 & Pneumopathy & No & M pneumoniae? & 20 days & No & No & No \\
\hline $32, \mathrm{M}$ & 8 & Pneumopathy & Ampicillin (2) & Infection or ampicillin & 10 days & Yes & No & No \\
\hline $33, \mathrm{M}$ & 9 & Hyperthermia & No & M pneumoniae & 30 days & No & No & No \\
\hline $34, \mathrm{~F}$ & 9 & Meningococcemia & $\begin{array}{l}\text { Ampicillin (2) } \\
\text { Clonazepam (2) }\end{array}$ & $\begin{array}{l}\text { Meningococcus or } \\
\text { drugs }\end{array}$ & 10 days & No & No & No \\
\hline $35, M$ & 9 & Upper respiratory tract infection & Ampicillin (2) & M pneumoniae or drug & 20 days & No & No & Ocular synechiae \\
\hline $36, \mathrm{~F}$ & 12 & $\begin{array}{l}\text { Pneumopathy } \\
\text { Immunisation } \ddagger\end{array}$ & No & $\begin{array}{l}M \text { pneumoniae } \\
\text { or immunisation } \ddagger\end{array}$ & 20 days & No & No & Labial synechiae \\
\hline $37, M$ & 12 & Upper respiratory tract infection & No & Infection & $\begin{array}{l}10 \text { to } \\
30 \text { days }\end{array}$ & $\begin{array}{l}\text { Yes }+ \\
\text { thalidomide }\end{array}$ & Yes & No \\
\hline $38, M$ & 13 & Pneumopathy & No & M pneumoniae & 20 days & No & No & No \\
\hline $39, \mathrm{~F}$ & 13 & None & Sulfametoxypyridamide (3) & Drug & 20 days & No & No & No \\
\hline \multicolumn{9}{|c|}{ Mucous membrane involvement only } \\
\hline $40, \mathrm{~F}$ & 4 & Hyperthermia & No & Herpes? (1) & 10 days & No & No & No \\
\hline $41, M$ & 10 & Immunisation $^{\star}$ & No & Immunisation $\dagger$ ? & 20 days & No & No & No \\
\hline $42, \mathrm{M}$ & 13 & Labial herpes & Ampicillin (2) & Herpes (2) or drug & 10 days & Yes & Yes & No \\
\hline
\end{tabular}

Herpes and drug scores are in brackets.

$\star$ Vaccine.

†Diphtheria-tetanus-poliomyelitis.

$\ddagger$ Hepatitis B. 
Table 3 Summary of causes in EM and SFS patients

\begin{tabular}{llll}
\hline & $E M$ & $S F S$ & Total \\
\hline Herpes & $8(+4 ?)$ & 0 & 12 \\
M pneumoniae & 0 & 5 (+5?) & 10 \\
Other infection and/or & 7 & 5 (including 1 MP) & 12 \\
$\quad$ immunisation & 3 (including 1 herpes) & 3 (including 1 MP) & 6 \\
Infection and/or drug & 1 & 1 & 2 \\
Drug & 22 & 17 & \\
Total & & & \\
\hline
\end{tabular}

herpes infection and in four other cases, herpes was strongly suspected. Recurrent labial herpes infection was responsible for eight of 10 cases of recurrent EM.

Mycoplasma pneumoniae was responsible for five of 17 cases of SJS, and strongly suspected in five others because of pulmonary symptoms during the disease.

Other infectious agents and immunisationOne case of EM (case 12) was associated with orf (ecthyma contagiosum). Streptococcus A was suspected in one case of EM (case 14), and meningococcus C in one case of SJS (case 34), although the girl had received drugs before the onset of cutaneous signs. Six cases (three EM, two SJS, and one mucous membrane involvement) could be attributed to immunisation 10 days before the onset of the disease (vaccine: diphtheria-tetanus-poliomyelitis in two; measles-mumps-rubella in one; and hepatitis $B$ in one). However, in two cases, an infectious disease was also associated.

Drugs

Fewer than $5 \%$ of patients had any disease attributed to drug intake only (two of 42 cases). These two cases were attributed to antibiotics (sulphamethoxypyridamine in SJS, case 39; and amoxycillin in EM, case 13). In eight cases, children were given antibiotics, mostly $\beta$ lactams, because of infectious symptoms at the onset of the disease. However, drug involvement could not be assessed according to current criteria. ${ }^{18}$

OUTCOME AND FOLLOW UP

No patient died. The mean duration of the disease was 12 days for EM and 18 days for SJS patients. Forty five per cent of EM patients had recurrent disease (10 cases of 22).

Ten patients received corticosteroids (prednisone or prednisolone $1 \mathrm{mg} / \mathrm{kg} /$ day for one week with progressive decrease). The mean disease duration was 16 days in patients treated with steroids (10 patients) versus 15 days in the non-steroid treated group.

Three patients received thalidomide for either acute illness (one case of SJS) or severe recurrent disease (one case of EM major and one case of SJS). While the patient with recurrent EM major was well controlled by thalidomide (case 22), the one with recurrent SJS, a 12 year old boy (case 37 ) had a severe recurrent disease of unknown aetiology (eight relapses in four years) with primary severe mucous membrane involvement and digestive bleeding as a result of oesophageal involvement confirmed by endoscopy. Relapses were initially controlled by thalidomide taken in the first hours of the disease, but then a severe relapse with skin

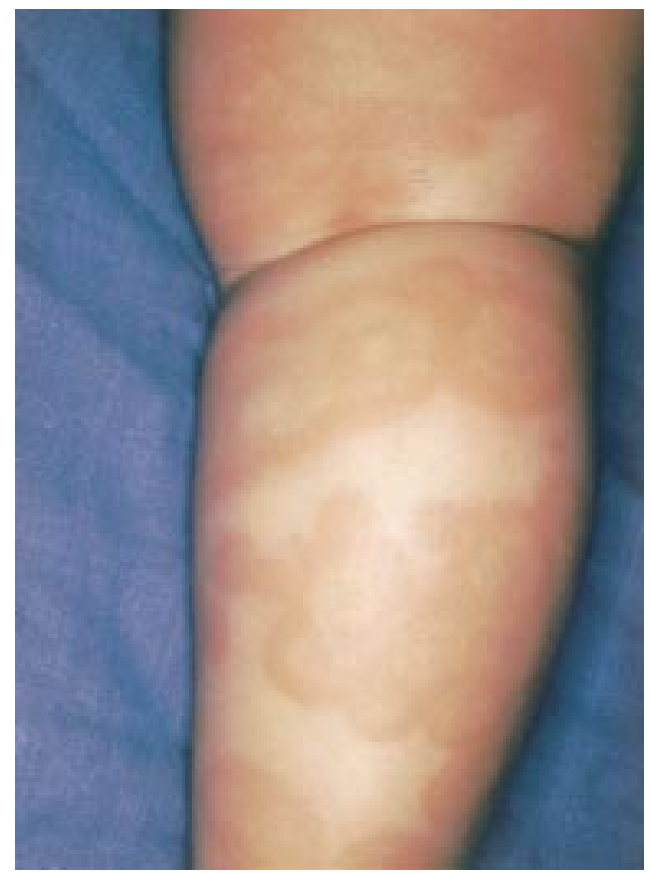

Figure 3 Example of most frequent EM misdiagnosis, acute urticaria with haemorrhagic cockade pattern.

involvement occurred as a result of MP infection and did not respond to the treatment.

Sequelae were minor in most cases including skin pigmentary changes, lip scars, mild ocular synechiae, and psychological disturbances in some cases of recurrent disease.

\section{Discussion}

In our series almost one third of children (24 of 77 cases) admitted to hospital for a suspected diagnosis of EM or SJS were misdiagnosed. The term EM is still confusing to nondermatologists and is usually applied to many acute eruptive disorders; usually the diagnosis can be easily corrected by a dermatologist or a consultant in paediatric dermatology. The most common misdiagnosis is acute urticaria, especially in cases of ecchymotic cockade pattern in infants ${ }^{1920}$ (fig 3). Other differential diagnoses include Kawasaki syndrome (fig 4) when there is cockade pattern rash or major mucous membrane involvement, acute haemorrhagic oedema, ${ }^{21}$ and maculopapular rash caused by drug intake.

In our experience, both EM and SJS can be considered as infection driven disorders. Even though the aetiology remains unclear in some patients, in most an infectious aetiology may be suspected on the grounds of various clinical, laboratory, and radiological arguments. The causes seem to be more viral than bacterial, except in MP infections. ${ }^{22}{ }^{23}$ In this series, MP infection was reponsible for almost two thirds of SJS cases, but was never associated with typical EM eruption. Thirty per cent of SJS patients had proven MP infection and in 30\% of the other cases MP infection could be suspected because of pulmonary symptoms. In childhood SJS, the probability of MP infection is high and the use of antibiotics such as erythromycin, which are usually effective against $\mathrm{MP}$, as first line treatment, can be advised. 


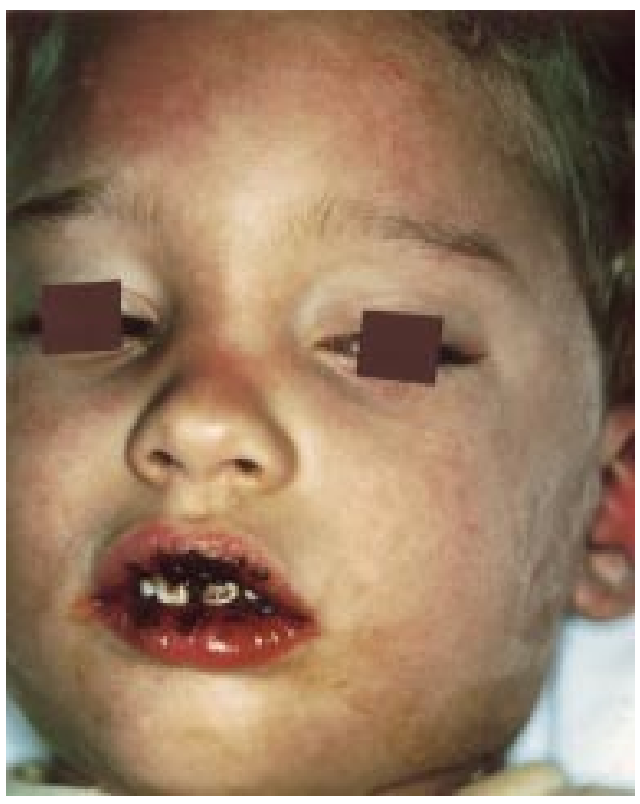

Figure 4 Kawasaki disease mimicking mucous membrane involvement of S7S.

Concerning viruses, our series confirms that typical childhood EM is related to herpes infection, ${ }^{56101317}$ as is recurrent EM. ${ }^{24} \mathrm{~A}$ labial herpes outbreak was noticed in $32 \%$ of cases and a recurrent labial herpes in $54 \%$ of EM cases ( $80 \%$ in recurrent EM). Unfortunately, it was retrospectively impossible to perform a polymerase chain reaction and isolate herpes DNA in skin lesions. ${ }^{26}$ No case of SJS could be attributed to herpes. Other viruses were incriminated in our series: orf (ecthyma contagiosum) in one case of EM (case reported in Ferrando and colleagues ${ }^{27}$ ); paravaccinia (cowpox) in one case of EM and one case of SJS; and paramyxovirus (measles) in one case of SJS.

EM and SJS were also associated with immunisation with living replicative viruses (measles), or viral antigens like those used in hepatitis $\mathrm{B}$ immunisation. ${ }^{28}$ In two cases the disease followed diphtheria and tetanus toxoid vaccination, ${ }^{29}$ and in one case EM was triggered by a tuberculin test, supporting the

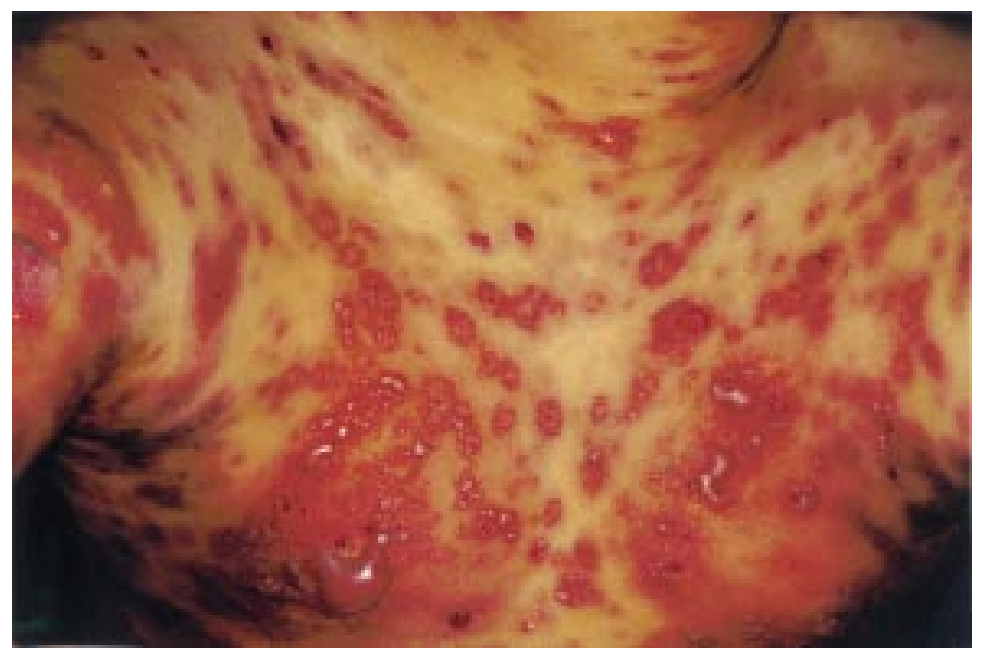

Figure 5 Blisters on the chest in a child with EM major (same patient as fig $1 \mathrm{~A}$ ). hypothesis that EM and SJS are a host specific response to a wide variety of infectious antigenic stimuli.

A similar phenomenon can be noted for adverse cutaneous drug reactions: cutaneous eruption may vary from benign maculopapular rash to Lyell syndrome and depend mainly on the host response to a single drug. ${ }^{30}$ Although Lyell syndrome in children is mainly a result of drug intake, ${ }^{81-33}$ in our experience EM and SJS are rarely related to medications. In both EM and SJS, many children were given drugs at the onset of the disease, especially antibiotics. However, the involvement of the drug could not be assessed. Only two cases were definitely attributed to drugs, the children having polymorphic cutaneous lesions, including maculopapular rash, target like macules, and major polymorphic cutaneous lesions with blisters. In one case typical targets of EM were present in association with mild mucous membrane involvement, so we diagnosed EM major and not SJS according to the criteria (case 13, figs $1 \mathrm{~A}$ and 5 ). The association in the same patient of various cutaneous lesions, such as pseudocockade pattern and blisters should point to drug eruption.

The use of corticosteroids is a still debated issue in EM of SJS. ${ }^{24-36}$ Some of our patients received corticosteroids, without any benefit in term of disease duration compared to children treated only with supportive care. Even though some authors recommend infusions of methylprednisolone in SJS, ${ }^{36}$ this treatment should be considered with circumspection, especially if an infectious aetiology is suspected.

The value of acyclovir in recurrent cases could not be assessed in this series. ${ }^{37}$ Thalidomide was used in severe or recurrent disease but it was retrospectively difficult to evaluate efficacy; and recently a detrimental effect has been reported in patients with toxic epidermal necrolysis. $^{38}$

In EM and SIS careful symptomatic treatment is essential. ${ }^{8231-33}$ Nursing should

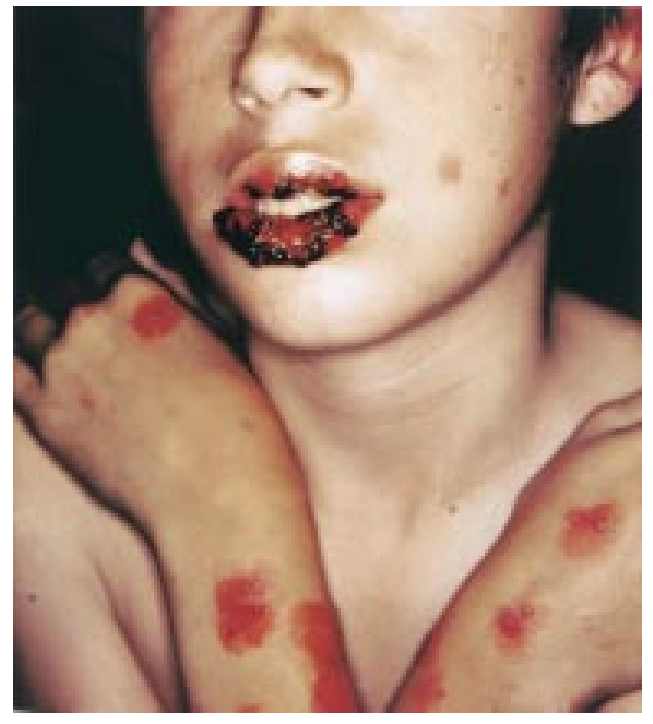

Figure 6 Atypical EM showing blisters on purpuric macules acrally distributed in a child with labial herpes. 
include meticulous skin and mucous membrane care, daily ophthalmological examination, and long term follow up when necessary. Antibiotic treatment is not thought to be necessary, except in case of MP infection. In children, severe cases of SJS are frequently complicated with major mucous membrane and oesophageal involvement, and intravenous fluids associated with nutritional support through a gastric tube may be helpful. With such symptomatic treatment, morbidity and sequelae are minor.

A standardised EM and SJS classification may be helpful for prospective investigations concerning their aetiology and physiopathology. Although consensus was easily obtained between the three experts in most cases of EM minor, it was more difficult to reach in some cases of EM major and SJS. Indeed, our children often presented both typical and atypical targets in association with blisters (figs $1 \mathrm{~A}$ and 5). On the other hand, atypical targets and purpuric macules were also seen in a typical acrally distributed EM pattern (fig 6). Furthermore, three children had only mucous membrane involvement and were unclassificable. We arbitrarily decided to classify patients as EM major and not SJS if typical cockades were present; however, this point is questionable, and suggests that an aetiological classification would be more satisfactory than a clinical classification based solely on skin eruption.

In conclusion, careful enquiry into drug intake is recommended, especially in cases of SJS or atypical EM; however, a drug induced eruption is not so frequent in our paediatric experience. Many viruses or bacteria can be trigger agents of EM and SJS, but the majority of cases are related to herpes and MP. MP infection is responsible for childhood SJS, a very severe condition justifying admission to a specialised unit. Herpes virus is responsible for typical minor or major EM and in most cases the disease is benign, even though of dramatic presentation. The main problem is recurrent EM which may require chronic therapy with acyclovir; thalidomide should be reserved for the most severe cases.

1 Hebra F von. Atlas der Hautkrankheiten. Vienna: Kaiserliche Akademie der Wissenchaften Wien, 1866.

2 Rasmussen JE. Erythema multiforme in children. Response to treatment with systemic corticosteroids. $\mathrm{Br} \mathcal{F}$ Dermatol 1976;95:181-6.

3 Ginsburg M. Stevens-Johnson syndrome in children. Pediatr Infect Dis 1982;1:155-8.

4 Maleville J, Massicot P, Ponge A, Guillard JM, Sarrat P, Guillet $G$. Aspects cliniques et étiologiques de l'érythème polymorphe. Sem Hôp Paris 1983;59:671-5.

5 Huff JC, Weston WL, Tonnesen MG. Erythema multiforme: a critical review of characteristics, diagnostic
criteria, and causes. $7 \mathrm{Am}$ Acad Dermatol 1983;8:763-75.

6 Howland WW, Golitz LE, Weston WL, Huff JC. Erythema multiforme: clinical, histopathologic, and immunologic multiforme: clinical, histopathologic, and

7 study. F Am Acad Dermatol 1984;10:438-46. multiforme in childhood and early infancy. Pediatr Dermatol $1986 ; 3: 135-9$.

8 Prendiville S, Hebert A, Greenwald J, Esterly B. Management of Stevens-Jonhson syndrome and toxic epidermal necrolysis in children. $\mathcal{F}$ Pediatr 1989;115:881-7.
9 Chan HL, Stern RS, Arndt KA, Langlois J, Jick SS, Jick H, Walker AM. The incidence of erythema multiforme, Stevens-Johnson syndrome, and toxic epidermal necrolysis. Arch Dermatol 1990;126:43-7.

10 Hurwitz S. Erythema multiforme: a review of its characteristics, diagnostic criteria, and management. Pediatr Rev 1990;11:217-22.

11 Salomon D, Saurat JH. Eythema multiforme major in a 2-month-old child with human immunodeficiency virus (HIV) infection. Br f Dermatol 1990;123:797-800.

12 Wolf P, Soyer HP, Fink-Puches R, Huff JC, Kerl H. Recurrent post-herpetic erythema multiforme mimicking poly-
morphic light and juvenile spring eruption: report of two cases in young boys. Br 7 Dermatol 1994;131:364-7.

13 Weston WL, Morelli JG, Rogers M. Target lesions on the lips: childhood herpes simplex associated with erythema multiforme mimics Stevens-Johnson syndrome. $7 \mathrm{Am}$ Acad Dermatol 1997;37:848-50.

14 Stevens AM, Johnson FC. A new eruptive fever associated with stomatitis and ophthalmia. Am $\mathcal{F}$ Dis Child 1922;24: 526-33.

15 Bastuji-Garin S, Rzany B, Stern RS, Shear NH, Naldi L, Roujeau JC. Clinical classification of cases of toxic epidermal necrolysis, Stevens-Johnson syndrome, and erythema multiforme. Arch Dermatol 1993;129:92-6.

16 Roujeau JC. What is going on in erythema multiforme? Dermatology 1994;188:249-50.

17 Assier H, Bastuji-Garin S, Revuz J, Roujeau JC. Erythema multiforme with mucous membrane involvement and Stevens-Johnson syndrome are clinically different disorders with distinct causes. Arch Dermatol 1995;131:539-43.

18 Begaud B, Evreux JC, Jouglard J, Lagier G. Imputabilité des effets inattendus ou toxiques des médicaments. Thérapie 1989;44:223-7.

19 Legrain V, Taïeb A, Sage T, Maleville J. Urticaria in infants: a study of forty patients. Pediatr Dermatol 1990;7:101-7.

20 Mortureux P, Léauté-Labrèze C, Legrain-Lifermann V, Lamireau T, Sarlangue J, Taieb A. Acute urticaria in infancy and early childhood. A prospective study. Arch Dermatol 1998;134:319-23.

21 Legrain V, Lejean S, Taïeb A, Guillard JM, Battin J, Maleville J. Infantile acute hemorrhagic edema of the skin: study of ten cases. F Am Acad Dermatol 1991;24:17-22.

22 Sontheimer RD, Garibaldi RA, Krueger GG. StevensJohnson syndrome associated with Mycoplama pneumoniae infections. Arch Dermatol 1978;114:241-4.

23 Tay YK, Huff C, Weston WL. Mycoplasma pneumoniae infection is associated with Stevens-Johnson syndrome, not erythema multiforme (von Hebra). F Am Acad Dermatol 1996;35:757-60.

24 Schofield JK, Tatnall FM, Leign IM. Recurrent erythema multiforme: clinical features and treatment in a large series of patients. Br f Dermatol 1993;128:542-5.

25 Huff JC, Weston WL. Recurrent erythema multiforme. Medicine 1989;68:133-40.

26 Brice SL, Krzemien D, Weston WL, Huff JC. Detection of herpes simplex virus DNA in cutaneous lesions of erythema multiforme. F Invest Dermatol 1989;93:183-7.

27 Ferrando MF, Léauté-Labrèze C, Fleury H, Taieb A. Orf and erythema multiforme in a child. Pediatr Dermatol 1997; 14:154-5.

28 Di lernia V, lo Scocco G, Bisighini G. Erythema multiforme following hepatitis B vaccine. Pediatr Dermatol 1994;11: 363-4.

29 Griffith RD, Miller OF. Erythema multiforme following diphtheria and tetanus toxoid vaccination. $\mathcal{F}$ Am Acad Dermatol 1998;19:758-9.

30 Bergoend H, Loffler A, Maleville J. Réactions cutanées survenues au cours de la prophylaxie de masse de la méningite cérébrospinale par un sulfamide long-retard. Ann Dermatol 1968;95:481-90.

31 Teillac D, Marsol P, Richard P, Hubert P, Roujeau JC, Cloup M, de Prost Y. Nécrolyse épidermique toxique de l'enfant (syndrome de Lyell). A propos de 18 cas. Arch Fr Pediatr 1987;44:583-7.

32 Adzick NS, Kim SH, Bondoc CC, Quinby WC, Remensnyder JP. Management of toxic epidermal necrolysis in a der JP. Management of toxic epidermal necrolysis in

33 Barone CM, Bianchi MA, Lee B, Mitra A. Treatment of toxic epidermal necrolysis and Stevens-Johnson syndrome in children. F Oral Maxillofac Surg 1993;51:264-8.

34 Esterly NB. Corticosteroids for erythema multiforme? Pediatr Dermatol 1989;6:229-50.

35 Renfro L, Grant-Kels JM, Feder HM Jr, Daman LA. Controversy: are systemic steroids indicated in the treatment of erythema multiforme. Pediatr Dermatol 1989; 6:43-50.

36 Kakourou T, Klontza D, Soteropoulou F, Kattamis C. Corticosteroid treatment of erythema multiforme major (Stevens-Johnson syndrome) in children. Eur $\mathcal{f}$ Pediatr 1997;156:90-3.

37 Bahmer FA, Zaun H, Luszpinski P. Thalidomide treatment of recurrent erythema multiforme. Acta Derm Venereol of recurrent eryt

38 Wolkenstein P, Latarjet J, Roujeau JC, et al. Randomised comparison of thalidomide versus placebo in toxic epidermal necrolysis. Lancet 1998;352:1586-9. 